\title{
Strategi Rantai Pasok Sayuran Organik Berbasis Petani di Kecamatan Pangalengan, Kabupaten Bandung
}

\author{
Supply Chain Strategy Development Based on Farmer of Organic Vegetables \\ in Pangalengan Sub-district, Bandung
}

\author{
Siti Kipdiyah ${ }^{* 1}$, Musa Hubeis ${ }^{\# 2}$ dan Budi Suharjo ${ }^{\# 3}$ \\ ${ }^{1}$ Bank Rakyat Indonesia (Persero) \\ Pusdiklat BRI JI. Harsono RM, Ragunan, Pasar Minggu, Jakarta Selatan 12550 \\ ${ }^{2}$ Departemen Manajemen, Fakultas Ekonomi dan Manajemen, Institut Pertanian Bogor \\ JI. Kamper, Kampus IPB Darmaga, Bogor 16680 \\ ${ }^{3}$ Departemen Matematika, Fakultas Matematika dan IImu Pengetahuan Alam, Institut Pertanian Bogor \\ Jl. Lingkar Kampus, Kampus IPB Darmaga, Bogor 16680
}

\begin{abstract}
ABSTRAK
Lifesyle sehat dengan slogan "Back to Nature" telah menjadi trend baru masyarakat. Direktorat Pengolahan dan Pemasaran, Departemen Pertanian di Indonesia telah memprakarsai program "Go Organik 2010" untuk meningkatkan mutu kehidupan dan lingkungan alam Indonesia dan untuk mendorong pengembangan pertanian organik dan daya saing berkelanjutan. Supply Chain Management (SCM) telah mewakili manajemen keseluruhan kegiatan pertanian yang melibatkan pengolahan, distribusi, pemasaran, hingga produk yang diinginkan kepada konsumen. Tujuan penelitian: (1) Mengidentifikasi karakteristik sayuran, para pelaku rantai pasokan, dan analisis deskriptif kondisi lingkungan di Pangalengan, (2) Mengidentifikasi faktor internal dan eksternal, (3) Perumusan strategi dengan matriks Strength, Weakneses, Opportunities dan Threats (SWOT), (4) Pemilihan strategi prioritas. Pengumpulan data dilakukan melalui teknik purposive sampling yang melibatkan 10 responden dan 3 ahli. Data yang digunakan adalah data primer dengan wawancara langsung, data sekunder dan studi pustaka. Pemilihan alternatif strategi dilakukan dengan menggunakan Analytical Hierarchy Process (AHP). Hasil penelitian menunjukkan bahwa pelaku rantai pasokan sayuran di Pangalengan adalah pemasok benih, petani, pedagang/kolektor, perusahaan, penjual/eksportir, pasar luar negeri, pasar tradisional dan ritel/supermarket. Hasil penelitian menunjukkan bahwa keselamatan sayuran untuk konsumen adalah kekuatan utama dan kelemahan utamanya terbatas keuangan. Selanjutnya, pendukung pemerintah adalah peluang besar dan ancaman utama adalah ketidakpastian iklim dan cuaca yang mempengaruhi produksi. Berdasarkan rumusan strategis, diperoleh tujuh strategi, pertama dan kedua strategi prioritas terkait dari pemasaran, yang memperluas pasar/distribusi dan meneliti perkembangan di pasar sayuran organik. Ketiga alternatif strategi yang mendukung pemerintah yang berhubungan strategi pengawasan. Selain itu, keempat dan kelima alternatif terkait dengan strategi keuangan, yang memantau dan mengawasi harga maka penguatan aspek keuangan. Keenam dan ketujuh alternatif yang berkaitan dengan strategi manajemen produksi, sedang merencanakan pertanian yang lebih baik dan meningkatkan mutu, kuantitas dan kontinuitas produksi.
\end{abstract}

Kata kunci: sayuran organik, rantai pasok, strategi, nilai tambah, petani

\section{ABSTRACT}

Healthy lifesyle with the slogan "Back to Nature" has become a new trend of the society. Directorate of Processing and Marketing, Ministry of Agriculture in Indonesia has initiated the program "Go Organic 2010" to improve the quality of life and the natural environment of Indonesia and to encourage the development of organic farming and sustainable competitiveness. Supply Chain Management (SCM) has represented overall management of agricultural activities which involved of processing, distribution, marketing, until the desired product to consumer. The Objectives of study included: (1) Identify the characteristics of the vegetables, the supply chain actors, and descriptive analysis of the environmental conditions in Pangalengan; (2) Identify internal and external factors; (3) The formulation of the strategy with the matrix SWOT; (4) Selection of priority strategy. The data was collected through purposive sampling technique which involving 10 respondents and 3 experts. The data used was primary and secondary data by direct interviews, questionnaires and literature study. Selection of strategic alternatives conducted using AHP. The result showed that the supply chain actors of vegetables in Pangalengan were seed suppliers, farmers, traders/collectors, the company, the seller/exporter, foreign

\footnotetext{
*) Korespondensi:

Pusdiklat BRI Jl. Harsono RM, Ragunan, Pasar Minggu, Jakarta Selatan 12550 ; e-mail: kipdiyahsiti@gmail.com
} 
markets, traditional market and retail/supermarket. The study showed that the safety of vegetables to consumer (score 0.336) was the main strength and the main weakness organic farming in Pangalengan was limited of financial (score 0.127). Futhermore, supporting of government was the major opportunity (score 0.127 ) and the major threat was uncertain of climate and weather which affected in production (score 0.144 ). Based on the formulation of strategic, the study obtained 7 strategy. The first and the second priority strategic related of the marketing, were expanding market/distribution to bussines partnerships (score 0.205) and researching of development in the organic vegetable's market (score 0.180). The third alternative strategic was supporting of government (score 0.157) which retaled to supervision strategy. Moreover, the fourth and the fifth alternatives related to strategy of financial, were monitoring and overseeing prices $(0.156)$ then strengthening of financial aspects (score 0.114). The sixth and the seventh alternatives related to production management strategy, were planning a better farming $(0.107)$ and improving the quality, quantity and continuity of production (score 0.081 ).

Key words: supply chain, organic vegetables; strategy, added value, farmers

\section{PENDAHULUAN}

Pertanian merupakan sektor yang sangat diperlukan bagi keberlangsungan kehidupan masyarakat Indonesia. Potensi pertanian di Indonesia tersebar secara merata di seluruh daerah. Komoditas hortikultura seperti sayursayuran mempunyai peranan yang sangat penting dalam peningkatan gizi masyarakat. Populasi Indonesia diperkirakan meningkat 1,3\% per tahun dan akan mencapai penduduk sekitar 250 juta jiwa pada tahun 2015 (Proyek Penelitian Sayuran Indonesia, 2009). Saat ini konsumsi sayuran per kapita warga Indonesia hanya 40,6 kg per tahun. Sementara rekomendasi dari Food and Agriculture Organization (FAO) konsumsi sayuran per kapita adalah 73 $\mathrm{kg}$ per tahun (Nuryati, 2012). Hal ini membuat Indonesia menjadi pasar yang sangat besar untuk produk sayuran segar maupun olahan.

Menurut Aliansi Organik Indonesia atau AOI (2009), pada tahun 2009 luas total areal pertanian organik di Indonesia 231.697 ha (Tabel 2). Dalam angka ini termasuk luas areal yang sudah sertifikasi pertanian organik (organik dan konversi), dalam proses sertifikasi, penjaminan sertifikasi oleh $\mathrm{AOI}$ dan tanpa sertifikasi.

Tabel 2. Luas areal pertanian organik di Indonesia 2009

\begin{tabular}{clr}
\hline No. & \multicolumn{1}{c}{ Jenis Pertanian Organik } & Luas (ha) \\
\hline 1. & Bersertifikat & 97.352 \\
2. & Dalam proses setifikasi (konversi) & 132.765 \\
3. & Penjaminan sertifikasi oleh AOI & 16 \\
4. & Tanpa sertifikasi & 1.564 \\
\hline \multicolumn{2}{c}{ Total } & 231.697 \\
\hline
\end{tabular}

Sumber: BPS, 2011.

Adanya kebijakan pemerintah mengenai program Go Organik 2010 tersebut maka sudah sewajarnya, jika pertanian di Indonesia mulai melirik adanya tanaman pangan organik. Hal ini merupakan peluang bagi para petani di Indonesia, khususnya daerah Jawa Barat sebagai salah satu daerah sentra produksi sayuran untuk mengubah pola budi daya konvensional ke pertanian organik yang bermutu guna meningkatkan pendapatan dan memenuhi peluang pasar nasional, maupun internasional yang memerlukan perubahan sistem produksi dan kelembagaan rantai pasokannya.

Permintaan sayuran organik yang berasal dari daerah Jawa Barat khususnya kabupaten Bandung mengalami peningkatan sampai $26 \%$ per tahun (Admin, 2012). Hal tersebut terkait dengan semakin meningkatnya kepedulian masyarakat terhadap mutu produk dan kesehatan. Komoditas sayuran sebanyak $50 \%$ di jual ke pasar Jakarta dan sekitarnya, 25\% di jual ke pasar kota Bandung dan sisanya ke pasar tradisional di beberapa daerah (Bapeda Kab. Bandung, 2010).

Salah satu upaya untuk memperbaiki sistem ketahanan pangan adalah mendesain sistem industrialisasi pertanian pangan yang mampu menghasilkan produk pangan dengan nilai tambah tinggi bagi petani, menjamin kelancaran pasokan pangan, terkendali tingginya mutu dan terjaminnya keamanan produk pangan serta terjangkaunya harga produk pangan oleh masyarakat. Hal ini dapat dilakukan melalui pengembangan strategi pengelolaan rantai pasokan (supply chain management) yang mengintegrasikan para pelaku dari semua segmen rantai pasokan, baik secara vertikal maupun horizontal (Apriantono, 2005).

Sistem pertanian industri dicirikan oleh usaha pertanian bernilai tambah tinggi dan terintegrasi dalam satu rantai pasokan (supply chain) berdasarkan relasi kemitraan sinergis dan adil dengan bertumpu pada sumber daya nasional, kearifan lokal, serta ilmu pengetahuan dan teknologi berwawasan lingkungan.

Tujuan kajian adalah (1) Mengidentifikasi faktor-faktor internal dan eksternal yang memengaruhi manajemen rantai pasok sayuran organik di Pangalengan; (2) Mengidentifikasi peranan para pelaku rantai pasok sayuran di Pangalengan; dan (3) Menyusun strategi rantai pasok yang sesuai untuk sayuran organik bernilai tambah tinggi berbasis petani di Pangalengan. 


\section{METODOLOGI}

Kegiatan dilakukan pada wilayah, atau penghasil produk sayuran, yaitu daerah Kecamatan Pangalengan, Kabupaten Bandung, Jawa Barat. Penelitian dilakukan selama enam bulan yang dimulai dari bulan Juni hingga November 2012.

Tahapan awal yang dilakukan adalah mengidentifikasi karakteristik produk sayuran potensial sebagai produk sayuran organik. Selain itu, dilakukan identifikasi para pelaku rantai pasok sayuran di Pangalengan dan melakukan analisis secara deskriptif kondisi lingkungan di Kecamatan Pangalengan. Penelitian dilakukan pada sentra penghasil produk sayuran organik di Kecamatan Pangalengan, Kabupaten Bandung. Tahap berikutnya adalah menganalisis faktor-faktor internal dan eksternal yang terkait dengan rantai pasok sayuran organik. Faktor-faktor ini dijabarkan melalui matriks Internal Factor Evaluation (IFE) dan External Factor Evaluation (EFE), kemudian dianalisis dengan menggunakan analisis Strenghts, Weaknesses, Opportunities and Threats (SWOT) untuk mengetahui kekuatan, kelemahan, peluang dan ancaman yang dihadapi oleh petani, kelompok tani (Poktan) dan gabungan kelompok tani (Gapoktan) dalam menjalani usaha pemasaran sayuran organik. Tahap akhir adalah memberikan keputusan alternatif strategi yang merupakan hasil dari pemetaan dari SWOT dengan menggunakan Analitycal Hierarcy Process (AHP).

Menurut Setiawan (2009), observasi terhadap supply chain yang ada dilakukan untuk mengidentifikasi sejumlah permasalahan yang sering muncul dalam Supply Chain Management (SCM) dan nilai tambah pada masing-masing pelaku rantai pasok sayuran. Komponenkomponen dari rantai pasok sayuran dataran tinggi terdiri dari pasokan yang berasal dari produksi internal, atau sendiri, mitra beli, atau mitra tani (Hadiguna, 2007).

Pengumpulan data dilakukan dengan teknik purposive sampling, yang melibatkan tenaga ahli, petani dan masyarakat pengguna sayuran organik. Data yang digunakan adalah data primer dan sekunder. Pengumpulan dilakukan melalui (1) Observasi lapangan, dari pengamatan langsung serta melakukan wawancara dengan para pelaku rantai pasok seperti petani, pedagang/pengumpul, konsumen/masyarakat sekitar, serta lembaga formal dan non formal yang terkait dengan rantai pasok produksi dan pemasaran sayuran organik. Jumlah minimal orang yang menjadi contoh yang akan diwawancarai sebanyak tiga orang dari masingmasing pelaku rantai pasok; (2) Opini Pakar, diperoleh dengan kuesioner SWOT yang disusun sesuai dengan analisis yang telah dilakukan sebelumnya. Analisis AHP dilakukan terhadap beberapa pilihan strategi untuk menda- patkan hasil pilihan strategi, maka memerlukan pertimbangan pendapat para ahli. Data sekunder diperoleh melalui studi pustaka (library research) dan informasi dari instansi terkait.

Karakteristik produk sayuran organik diidentifikasi menggunakan analisis deskriptif untuk memperoleh gambaran umum dan mendalam mengenai karakteristik produk sayuran organik yang ada di Kecamatan Pangalengan, Kabupaten Bandung, serta mengidentifikasi peranan para pelaku rantai pasok sayuran. Formulasi strategi diintegrasikan ke dalam tiga tahap kerangka pengambilan keputusan (David, 2010), yaitu tahap pengumpulan input (the input stage), pemanduan (the matching stage) dan penetapan keputusan strategi (the decision stage).

Tahap Input terdiri atas Matriks EFE, Matrix CPM dan Matriks IFE. Membuat keputusan kecil dalam matriks input berhubungan dengan tingkat penting relatif dari faktor internal dan eksternal memungkinkan penyusun strategi untuk menghasilkan dan mengevaluasi alternatif strategi dengan efektif. Penilaian intuitif yang baik, selalu dibutuhkan untuk menentukan bobot dan peringkat yang sesuai.

Tahap pemaduan dari kerangka kerja perumusan strategi terdiri atas empat teknik yang dapat digunakan, yaitu matriks SWOT dan Internal-External (IE). Alat ini bersandar pada informasi yang diturunkan dari tahap input untuk mencocokkan peluang dan ancaman eksternal dengan kekuatan dan kelemahan internal.

Tahap keputusan, dimana analisis dan intuisi memberikan dasar untuk membuat keputusan perumusan strategi dengan menggunakan analisis AHP. Teknik pencocokkan mengungkapkan alternatif strategi yang layak. Banyak dari strategi ini kemungkinan diajukan oleh manajer dan karyawan yang berpartisipasi dalam aktivitas analisis dan pilihan strategi. Strategi tambahan yang dapat dihasilkan dari analisis pencocokan dapat didiskusikan dan ditambahkan ke dalam daftar pilihan alternatif yang layak.

\section{HASIL DAN PEMBAHASAN}

Kecamatan Pangalengan merupakan wilayah dengan curah hujan tertinggi di Kabupaten Bandung. Berdasarkan data curah hujan di Kecamatan Pangalengan mengacu pada data curah hujan di Kabupaten Bandung, rataan curah hujan tahunan 1.718-2.603 $\mathrm{mm} /$ tahun. Secara garis besar musim hujan, atau bulan-bulan basah (curah hujan rataan bulanan $230 \mathrm{~mm}$ ) terjadi mulai bulan Oktober, atau November dan musim kemarau, atau bulan-bulan kering (curah hujan < $100 \mathrm{~mm}$ ) terjadi pada bulan Mei atau Juni. Suhu udara di Kecamatan Pangalengan berkisar $15^{\circ}-23^{\circ} \mathrm{C}$. Penyediaan air di Kecamatan Pangalengan diperoleh dari penyediaan air tanah dan air 
permukaan. Sumber air permukaan Kecamatan Pangalengan yaitu terpusat pada aliran Sungai Citarum dengan beberapa anak sungai antara lain Sungai Cisurili, Sungai Cisangkuy, Sungai Cibeureum dan Sungai Cibudug.

Penggunaan lahan paling luas di Kecamatan Pangalengan adalah untuk perkebunan Teh (6.761 ha), sedangkan untuk persawahan hanya 118 ha. Potensi kawasan Kecamatan Pangalengan untuk pengembangan, antara lain untuk kawasan hutan produksi, kawasan pangan lahan basah, kawasan tanaman tahunan/ perkebunan, kawasan peternakan, arahan untuk pengembangan agroindustri dan kawasan pariwisata. Kawasan untuk perkebunan/tanaman tahunan paling luas (6753 ha).

Jenis mata pencaharian penduduk Pangalengan sangat bervariasi, mulai dari sektor agaris, perdagangan, kerajinan, pemerintahan dan jasa. Jumlah petani di Kecamatan Pangalengan adalah 25.756 orang (71,27\%), pengrajin 523 orang $(1,44 \%)$, pedagang 5.630 orang $(15,57 \%)$, jasa 2.783 orang $(7,7 \%)$ dan PNS/Polri/TNI 1.446 orang (4\%). Dengan demikian sebagian besar mata pencaharian masyarakat Pangalengan adalah bertani. Hal ini dipengaruhi oleh ketersediaan SDA, SDM dan fasilitas sosial sebagai pendukung.

Kondisi SDM masyarakat Pangalengan berdasarkan indikator pendidikan pada masingmasing desa hanya tamatan sekolah dasar (SD) dan sekolah menengah pertama (SMP). Untuk tamatan sekolah menengah umum (SMU) sedikit dan tamatan sarjana sangat sedikit. Di desa Pangalengan dan Margamukti paling banyak SDM tamatan Sarjana.

Lahan-lahan pertanian di Kecamatan Pangalengan sangat subur dan produktif. Sebagian besar lahan tersebut dimanfaatkan untuk menanam komoditas sayur-sayuran. Oleh karena itu, Kabupaten Bandung merupakan salah satu wilayah yang mempunyai potensi untuk dikembangkan sebagai kawasan Agropolitan. Salah satunya Kecamatan Pangalengan yang diperkirakan mempunyai potensi sentra produksi pangan prospektif dan perlu dikembangkan dengan pendekatan yang sistemik.

Pengembangan kawasan Agropolitan pada prinsipnya adalah upaya peningkatan nilai tambah pertanian dilokalisir terjadi di dalam kawasan tersebut. Untuk itu diperlukan potret komoditas yang antara lain meliputi proses produksi, proses pengolahan dan proses pemasaran. Komoditas di Pangalengan dibedakan berdasarkan jenisnya, yaitu (1) komoditas tanaman pangan dan hortikultura, (2) komoditas buah-buahan, (3) komoditas perkebunan dan (4) komoditas peternakan. Jenis tanaman pangan dan hortikultura yang terdapat di Kecamatan Pangalengan adalah Cabe, Bawang putih, Bawang merah, Tomat, Sawi, Kentang, Kubis, Mentimun, Buncis, Brokoli, Terong dan Sosin.
Kentang merupakan sayuran yang paling banyak diproduksi, yaitu 270.199 Ton dengan luas lahan 3.584 ha. Desa Margamukti merupakan desa yang memproduksi sayuran kentang paling banyak (BPS, 2011). Di Kecamatan Pangalengan adalah Tomat (BPS, 2011) dengan total produksi 51.512 ton pada areal 1.105 ha. Sayuran Sawi juga merupakan sayuran potensial yang dikembangkan di Kecamatan Pangalengan dengan produksi 31.575 ton dan luas lahan 1.643 ha. Sayuran Buncis merupakan sayuran paling banyak diproduksi (7.683,9 ton) dengan luas lahan 372 ha. Brokoli juga merupakan sayuran yang potensial diproduksi di Kecamatan Pangalengan yaitu 4.707 ton produksinya. Untuk sayuran Terong dan Sosin tidak diproduksi di Kecamatan Pangalengan (BPS, 2011).

\section{Identifikasi Rantai Pasok}

Rantai pasokan terdiri dari serangkaian kegiatan produktif yang terhubung antara aktifitas nilai yang satu dengan yang lainnya membentuk rantai nilai industri. Anggota utama rantai pasok sayuran di Kecamatan Pangalengan terdiri dari pemasok bibit sayuran, petani sayuran sebagai produsen, pedagang atau pengumpul sebagai agen yang mengumpulkan/ membeli sayuran dari petani, penjual/eksportir, perusahaan dan terakhir adalah konsumen yang terdiri dari pasar luar negeri, pasar tradisional (dalam negeri) dan ritel/supermarket. Modelmodel struktur rantai pasokan sayuran di Kecamatan Pangalengan disajikan pada Gambar 1.

Setiap anggota atau pelaku rantai pasokan sayuran di Pangalengan mempunyai peran yang berbeda. Peran masing-masing anggota dalam model rantai pasok dapat dilihat dalam Tabel 1.

Beberapa sayuran yang utama di Pangalengan adalah kentang, tomat, buncis, kubis, dan sawi. Untuk komoditi sayuran kentang terdapat beberapa macam jenis yang di jual di pasar tersebut. Sebagai contoh, kentang superior dengan harga Rp4.000/kg dan kentang Atlantik Rp4.500/kg. Jenis kentang Atlantik kebanyakan penjualannya terikat kontrak langsung antara petani/kelompok tani dengan PT Indofood Sukses Makmur (ISM). Untuk komoditi sayuran lainnya, seperti tomat Rp800/kg-Rp2.500/kg dan Sawi Rp1.100/kg.

Pemasaran komoditi sayuran dari para pedagang, atau pengumpul tersebut kebanyakan, yaitu Pasar Bandung, Bogor, Jakarta, Pasar Tangerang, Pasar Induk Kramajati, Pasar Kemang Bogor dan Pasar Caringin Bandung. Untuk Kentang, Kol dan Tomat, biasanya dipasarkan di daerah Pontianak, sedangkan beberapa kelompok tani bermitra dengan perusahaan ekspor, antara lain PT ISM dan PT Alamanda. 


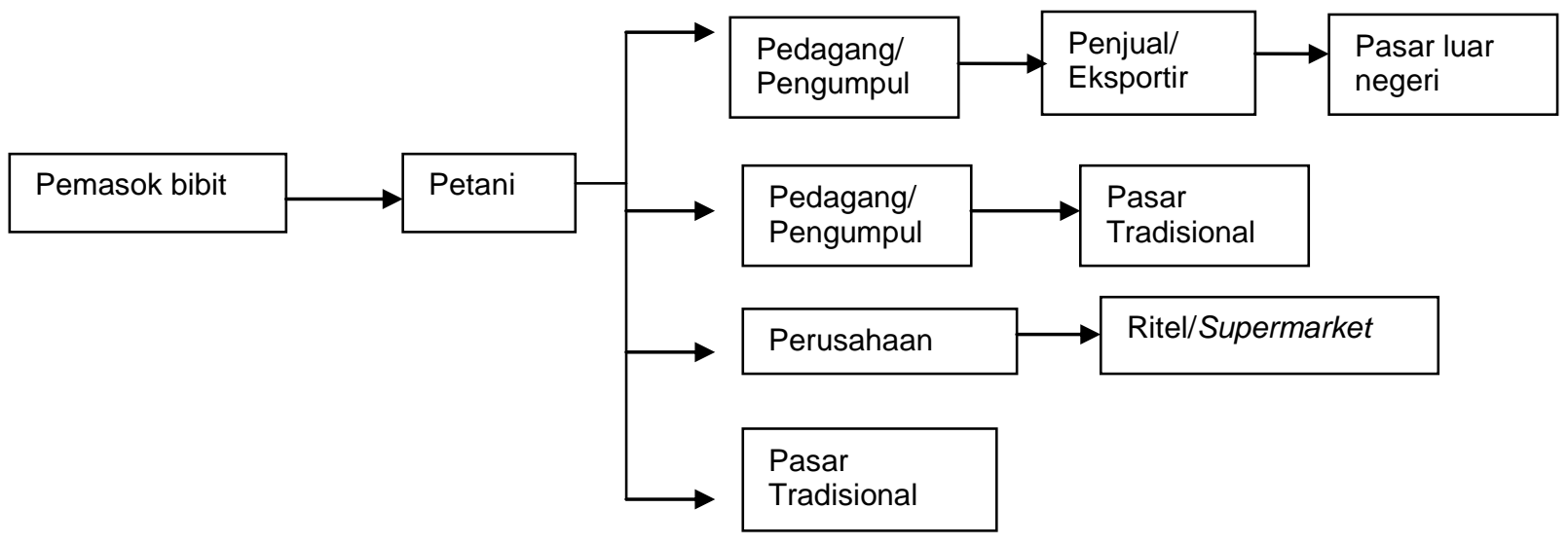

Gambar 1. Identifikasi stuktur rantai pasok sayuran di Kecamatan Pangalengan

Tabel 1. Anggota rantai pasokan sayuran di Pangalengan

\begin{tabular}{|c|c|c|c|}
\hline Tingkatan & Pelaku & Proses & Aktivitas \\
\hline Produsen & $\begin{array}{ll}\text { - } & \text { Pemasok bibit } \\
\text { - } & \text { Petani (kelompok tani) }\end{array}$ & $\begin{array}{l}\text { - } \text { Budidaya } \\
\text { - Pembelian } \\
\text { - Distribusi } \\
\text { - Penjualan }\end{array}$ & $\begin{array}{l}\text { - Melakukan budidaya bibit dan } \\
\text { produksi sayuran } \\
\text { - Menjual ke distributor }\end{array}$ \\
\hline Distributor & $\begin{array}{l}\text { - Pedagang/Pengumpul } \\
\text { - Perusahaan } \\
\text { - Eksportir }\end{array}$ & $\begin{array}{l}\text { - } \text { Pembelian } \\
\text { - Sortasi } \\
\text { - } \text { Grading } \\
\text { - Pengemasan } \\
\text { - Pelabelan } \\
\text { - Pengemasan }\end{array}$ & $\begin{array}{l}\text { - Melakukan pembelian sayuran dari } \\
\text { petani } \\
\text { - Melakukan proses untuk } \\
\text { menambah nilai jual sayuran } \\
\text { - Melakukan distributor ke } \\
\text { konsumen }\end{array}$ \\
\hline Konsumen & $\begin{array}{l}\text { - } \text { Pasar luar negeri } \\
\text { - } \text { Pasar tradisional } \\
\text { - Ritel/Supermarket } \\
\text { - } \text { Masyarakat umum }\end{array}$ & - - Kembelian & $\begin{array}{l}\text { - Melakukan pembelian dari } \\
\text { distributor } \\
\text { - Melakukan konsumsi sayuran }\end{array}$ \\
\hline
\end{tabular}

Aliran finansial pada rantai pasokan sayuran di Pangalengan terjadi dari konsumen, pengekspor atau penjual, pengumpul/pedagang, perusahaan atau langsung ke petani dan kemudian ke pemasok bibit. Mekanisme pembayaran untuk rantai pasok hilir adalah pembayaran transfer/tunai. Di rantai hulu, dari pedagang/pengumpul ke petani kebanyakan dilakukan pembayaran dua kali sebelum dan setelah sayuran laku terjual.

Beberapa penjual besar atau seperti perusahaan ekspor ada yang melakukan sistem kontrak kepada para petani, yaitu perusahaan memberikan pinjaman modal untuk para petani. Pinjaman modal tersebut dikembalikan setelah petani menjual kembali sayurannya, atau pembayarannya dengan cara mengurangi harga penjualan. Pinjaman tersebut sebagai pengikat, agar petani tidak menjual sayuran yang telah diproduksi ke pedagang atau perusahaan lainnya. Didalam sistem kontrak tersebut, harga sayuran menjadi lebih murah dibandingkan penjualan ke pedagang/pengumpul.

Terdapat beberapa model struktur rantai pasokan. Dalam setiap struktur rantai terdapat perbedaan peran masing-masing anggota, juga memiliki pola berbeda-beda. Pola tersebut dibangun berdasarkan kemudahan aplikasi di lapangan dan upaya untuk menghemat biaya. Dalam setiap aliran distribusi bahan agro tersebut yang berperan adalah para pelaku rantai pasok. Menurut Marimin dan Maghfiroh (2010), keberhasilan kelembagaan rantai pasok komoditas pertanian tergantung pihak-pihak yang terlibat mampu menerapkan kunci sukses (key succes factor) yang melandasi setiap aktivitas di dalam kelembagaan tersebut. Kunci sukses ini teridentifikasi melalui penelusuran yang detail dari setiap aktivitas didalam rantai pasokan. Kunci sukses tersebut adalah trust building, koordinasi dan kerjasama, kemudahan akses pembiayaan dan dukungan pemerintah.

\section{Identifikasi pemasok bibit sayuran dan pupuk} Persediaan pupuk kandang di Pangalengan sebagian besar berasal dari daerah Kecamatan Sukabumi. Operasi pengangkutan pupuk kandang berlangsung per harinya mencapai 8-20 truk yang dikirim ke Pasar Pangalengan. Masing-masing truk memuat kurang lebih 6 ton pupuk kandang dengan asumsi per karung $30 \mathrm{Kg}$. Harga untuk pupuk Rp7.000/karung. Harga pupuk tersebut setiap harinya terjadi perubahan.

Penjual dan petani melakukan sistem pembayaran secara langsung setelah terjadi 
kesepakatan harga antara kedua pihak. Pengangkutan, atau transportasi dilakukan dengan menggunakan kendaraan bak, atau truk, biaya transportasinya ditanggung oleh pihak pembeli/petani. Biaya transportasi untuk sekali perjalanan sekitar satu juta rupiah. Dalam hal ini terjadi efisiensi dari kendaraan yang digunakan, karena kendaraan yang digunakan untuk pengangkutan pupuk, dapat digunakan untuk mengangkut hasil komoditi sayuran untuk dipasarkan ke pasar-pasar tradisional.

Para petani, atau Poktan di Kecamatan Pangalengan melakukan kegiatan sebagai pemasok bibit sayuran untuk memasok petani lain di Pangalengan sendiri. Kegiatan para petani pemasok bibit dapat dikatakan sebagai pekerjaan utamanya. Kebanyakan para petani melakukan budidaya bibit/benih sayuran pernah melakukan pelatihan yang berhubungan dengan pembibitan yang biasanya diselenggarakan oleh Balai Benih Induk dari Dinas pertanian setempat. Dalam menjalankan usahanya, para Poktan untuk pembibitan beranggotakan kurang lebih tujuh petani. Jenis bibit yang dibudidayakan pada umumnya bibit sayuran yang sering ditanam oleh petani lain, seperti bibit granula Kentang, Tomat, Sawi dan Buncis. Jumlah bibit yang dijual biasanya per empat (4) bulan sekali atau tergantung jenis sayurannya. Sebagai contoh untuk bibit kentang, sekali penjualan dapat mencapai 50 ton bibit Kentang per empat bulan. Harga dari bibit sendiri dapat mencapai Rp18.000,00/Kg. Dalam menjalankan kegiatan usaha pemasokan bibit sayuran, para Poktan melakukan koordinasi dan kerjasama antara Poktan pemasok lainnya.

Beberapa sumber bibit/benih berasal dari budidaya milik sendiri, dari sesama pemasok dan ada yang berasal dari alam. Rataan para kelompok tani memiliki lahan untuk pembibitan dengan luas berhektar-hektar. Biaya awal untuk melakukan rataan pembibitan Rp63 juta per hektar. Dalam melakukan kegiatan pembibitan terdapat berbagai kendala. Kendala yang sering dihadapi dalam melakukan pembibitan adalah hama dan air (musim). Selain kendala alam juga kendala pemasaran, terkadang petani tidak membutuhkan bibit yang berasal dari lingkungan sendiri, sehingga petani yang melakukan pembibitan kebanyakan juga melakukan usaha produksi pertanian sayuran sendiri.

\section{Identifikasi petani sayuran}

Sayuran yang diproduksi oleh petani di Kecamatan Pangalengan merupakan gabungan hasil produksi para petani secara individual maupun dalam suatu wadah, atau Poktan. Pembentukan Poktan dimaksudkan untuk membantu para petani mengorganisasikan dirinya, terutama dalam meningkatkan produktivitas, efisiensi usaha, permodalan, akses pasar, akses teknologi dan informasi, serta meningkatkan kesejahteraan para petani. Saat ini Poktan yang ada di Kecamatan Pangalengan berjumlah 155 petani.

Peranan Poktan yang ada di Kecamatan Pangalengan membawa harapan besar bagi para petani. Dengan adanya Poktan, para petani memiliki pola tanam teratur, pengolahan lahan yang lebih baik dan kemudahan dalam mendapatkan bibit sayuran unggulan. Kemudian para petani mampu membina kontrak kerjasama dengan perusahaan agribisnis, terutama dalam memenuhi permintaan (kuota) harian, mingguan, maupun bulanan.

Petani di Kecamatan Pangalengan rataan berjenis kelamin pria dengan kategori dewasa, namun ada juga ditemukan para Poktan khusus wanita yang jumlahnya sangat sedikit. Status kepemilikan akan lahan yang dibudidayakan kebanyakan adalah milik sendiri, namun beberapa Petani menyewa dari petani lainnya. Dalam suatu Poktan rataan terdiri minimal lima orang Petani. Kebanyakan para petani memiliki tenaga petani lainnya yang digaji dengan sistem upah mingguan.

Pola budidaya yang paling banyak diterapkan di Pangalengan adalah polikultur atau tumpangsari. Produktivitas hasil panen untuk masing-masing Poktan berbeda, biasanya dalam satu tahun sayuran dapat dipanen 3 kali panen. Dalam hal pembibitan atau pembenihan kebanyakan petani sudah memiliki rekanan sesama petani pemasok bibit di Pangalengan. Namun, ada juga yang melakukan pembibitan sendiri untuk digunakan sendiri. Para Petani yang melakukan budidaya pembenihan secara sendiri, dikarenakan para Petani pemasok bibit tidak konsisten dalam menyediakan benih, serta biasanya mutu bibit yang dihasilkan tidak sesuai dengan harapan petani sayuran.

Petani Pangalengan mengatasi adanya hama dan penyakit sayuran dengan tindakan pencegahan secara fisik maupun kimia. Akan tetapi kebanyakan para Petani memilih bahanbahan kimia untuk memberantas hama dan penyakit yang menyerang sayuran. Hal tersebut yang menjadi salah satu kendala permasalahan dalam menuju pertanian organik di Pangalengan. Dalam hal pengawasan mutu, petani melakukan proses sorting dan grading terhadap produk sayurannya. Namun, kebanyakan Petani tidak melakukan pengemasan dan pelabelan sendiri.

Pemerintah Pangalengan setempat, yaitu Dinas Penyuluh Pertanian telah melakukan pembinaan dan pelatihan terhadap pengawasan mutu sayuran. Hal tersebut dilakukan agar mutu sayuran di Pangalengan sesuai dengan harapan konsumen di pasar. Dalam aspek pemasarannya, para petani melalukan penjualan di pasar Pangalengan. Di pasar tersebut terjadi pertemuan antara petani dengan para pedagang/ pengumpul, dimana kesepakatan harga sesuai dengan persetujuan kedua belah pihak. Namun, banyak Poktan yang menjalin kerjasama atau 
bermitra dengan perusahaan besar seperti PT Alamanda (perusahaan eksport sayuran) dan PT ISM. Para petani di Pangalengan tidak melakukan kegiatan promosi dalam memasarkan produk sayurannya, sehingga hal ini dapat mengurangi biaya operasional petani. Akan tetapi hal tersebut juga dapat berdampak merugikan petani, karena akses pasar menjadi terbatas.

Wilayah pemasaran Petani kebanyakan di pasar-pasar dalam satu Kabupaten dan satu Provinsi. Untuk wilayah antar provinsi dan ekspor, petani hanya menjadi produsen untuk didistribusikan ke distributor lainnya. Dalam melakukan pemasaran, rataan Petani tidak mengalami kendala. Namun, adanya pasar yang hanya terbatas dan peran Petani sebagai produsen mengakibatkan keuntungan Petani menjadi cenderung kecil. Hal tersebut dikarenakan juga para Petani tidak melakukan penjualan secara langsung ke konsumen, sehingga besar kemungkinan harga produk untuk Petani menjadi rendah.

Dalam hal permodalan, Petani kebanyakan memiliki modal sendiri, atau dibantu oleh keluarga, namun sebagian juga berasal dari pinjaman dari Bank. Dalam hal produksi, Kecamatan Pangalengan sebagai salah satu sentra pertanian sayuran unggulan di Kabupaten Bandung memiliki luas lahan 10.888 Ha dengan produksi 441.256 ton. Sayuran yang diproduksi saat ini adalah sayuran yang aman untuk dikonsumsi dan memenuhi standar kesehatan (Prima III). Pertanian Prima III yang diterapkan para petani merupakan langkah awal dan secara gradual menuju pertanian organik. Penggunaan pestisida dan insektisida merupakan suatu kebutuhan untuk mempertahankan kuantitas produksi dan dosis yang digunakan masih dalam batas normal.

Pedoman budidaya sayuran baik (GAP) yang sesuai dengan kondisi Indonesia sebagai panduan dalam proses produksi untuk menghasilkan produk yang aman dikonsumsi, bermutu dan diproduksi secara ramah lingkungan. Perwujudan penerapan budidaya sayuran yang baik dinyatakan dengan penerbitan nomor registrasi yang diberikan sebagai hasil penilaian kebun, atau lahan usaha. Komoditi sayuran unggulan di Kecamatan Pangalengan adalah Kentang 270.199,4 ton pada lahan $3.584 \mathrm{Ha}$, Kubis $52.753,1$ ton pada lahan $2.403 \mathrm{Ha}$, Sawi $31.574,7$ ton pada lahan $1.643 \mathrm{Ha}$, Tomat 51.512 ton pada lahan $2.403 \mathrm{Ha}$ dan Buncis $7.683,9$ ton pada lahan $372 \mathrm{Ha}$.

\section{Identifikasi pedagang/pengumpul sayuran}

Sistem penjualan sayuran di Kecamatan Pangalengan berlangsung berdasarkan dari permintaan pasar. Hal ini artinya para pedagang/ bandar dan petani melakukan transaksi dan negosiasi terhadap produk, serta harga. Setelah terjadi kesepakatan harga dari kedua pihak, maka pihak pedagang dapat langsung mema- nen/mengambil sayuran di kebun milik Petani. Setiap hari transaksi di pasar tersebut berlangsung, sehingga sering terjadi perubahan harga sayuran. Misalnya, untuk komoditi Kentang, terdapat beberapa harga tergantung dari jenis dan kebijakan di pasar Pangalengan sendiri.

Kebijakan harga sayuran di Pangalengan bergantung juga harga di pasaran dan kesepakatan dari para Petani. Untuk sayuran kentang berjenis Atlantik yang diproduksi di Pangalengan tidak dipasarkan di pasar biasa, karena untuk jenis tersebut sudah terikat kontrak dengan PT ISM, sehingga untuk bibit kentang Atlantik sudah disediakan dari pihak ISM, kemudian para Petani yang dipilih untuk membudidayakannya secara langsung menjual ke perusahaan kembali. Hal tersebut juga berlaku untuk penjualan sayuran lainnya yang telah terikat dengan perusahaan besar lainnya seperti PT Alamanda. PT Alamanda tersebut merupakan salah satu perusahaan ekspor sayuran yang ikut berperan dalam bantuan dana dan bibit kepada para Petani di Pangalengan.

Penjualan sayuran yang dilakukan oleh pedagang/pengumpul bervariasi. Rataan setiap harinya para pedagang bisa mengangkut satu kendaraan bak/truk dengan asumsi kapasitasnya dapat mencapai enam ton sayuran. Kendaraan bak/truk yang digunakan untuk pengangkutan sayuran ke pasar dan juga untuk mengangkut pupuk dari pasar untuk dijual ke para petani di Pangalengan. Hal tersebut untuk mengefisienkan biaya transportasi, sehingga masing-masing pihak dapat saling menguntungkan.

Pemasaran sayuran tersebut kebanyakan ditujukan ke pasar-pasar di Bandung, Bogor, Jakarta, Pasar Tangerang, Pasar Induk Kramatjati, Pasar Kemang Bogor dan Pasar Caringin Bandung. Untuk Kentang, Kol dan Tomat, biasanya dipasarkan antar Provinsi, yaitu di daerah Pontianak. Selain di pasar-pasar, pemasaran juga ke swalayan/supermarket dan perusahaan (sistem kontrak). Penjualan yang dilakukan oleh para pedagang/pengumpul skala besar di Pangalengan sudah tertata dengan baik. Sistem manajemennya seperti yang dilakukan oleh Perusahaan Dagang (PD) Hikmah, dengan manajemen modern menggunakan tenaga profesional yang berasal dari keluarga maupun profesional lainnya. Dalam pengembangan agribisnis, perusahaan membeli Kentang dari masyarakat, atau Petani dengan harga pasar dari Poktan, sedangkan pengadaan bibit, pupuk dan pestisida ditanggung oleh PD Hikmah sendiri. Dalam usahanya PD Hikmah juga telah melakukan kerjasama dan kemitraan dengan berbagai perusahaan besar.

Para Petani di Pangalengan melakukan ikatan kontrak kerjasama dengan perusahaan agribisnis, usaha olahan, perhotelan dan pelaku usaha lain yang membutuhkan kepastian produk. Sistem kontrak sebenarnya mengun- 
tungkan kedua belah pihak (petani dan mitranya). Dengan sistem kontrak ini akan menjamin kuantitas, mutu dan kontinuitas produk bagi pelaku usaha. Manfaat bagi petani adalah harga yang ditetapkan di atas harga pasar tradisional, kestabilan harga selama periode tertentu, bantuan modal, bantuan benih dan prosedur budi daya sayuran. Komoditas yang dijual dengan sistem kontrak biasanya akan dipasarkan di berbagai pasar modern (supermarket atau swalayan), hotel dan perusahaan agribisnis untuk tujuan ekspor. Petani yang belum memiliki ikatan kontrak pemasaran akan menjual sayurannya kepada konsumen akhir ataupun pembeli dalam jumlah besar (agen, bandar, tengkulak dan pedagang/ pengumpul).

\section{Identifikasi konsumen sayuran organik}

Kebanyakan konsumen sayuran organik adalah perempuan dengan rataan pendidikan sarjana dan kebanyakan profesinya pegawai negeri. Para konsumen memilih sayuran organik, karena konsumen menyadari akan pentingnya kesehatan bagi tubuh. Selain itu salah satu alasan lain adalah karena konsumen mengetahui bahwa sayuran organik memiliki kandungan mutu dan gizi yang lebih baik dibandingkan dengan sayuran biasa. Alasan lainnya, para konsumen merupakan vegetarian, sehingga konsumen tidak rugi untuk mengeluarkan biaya lebih untuk mendapatkan sayuran yang bermutu tinggi. Rataan konsumen membeli sayuran organik 3-4 kali dalam sebulan dan jenis sayuran yang dibeli juga bervariasi 2-3 jenis sayuran organik.

Awal dari ketertarikan para konsumen memilih untuk mengkonsumsi sayuran organik, kebanyakan dikarenakan adanya iklan di swalayan yang mempromosikan sayuran organik. Dengan kata lain, konsumen lebih memilih dan tertarik untuk membeli sayuran organik di Swalayan daripada di pasar tradisional. Hal tersebut dikarenakan sayuran yang dijual di Swalayan lebih segar daripada pedagang sayur keliling dan juga karena kebanyakan tempat tinggalnya lebih dekat dengan Swalayan. Menurut para konsumen sayuran organik, yang menjadi indikator bermutunya sayuran organik adalah mutu kesegaran dari sayurannya. Selain itu para konsumen berpikir bahwa sayuran organik yang mereka beli baik untuk kesehatan tubuh karena tidak menggunakan bahan pestisida, bersih dan segar.

\section{Analisis Lingkungan Usaha}

\section{Identifikasi faktor internal}

Lingkungan internal dianalisis menggunakan pendekatan fungsional, yaitu analisis yang dilakukan pada masing-masing fungsi dalam kelompok tani dengan mengkaji manajemen, pemasaran, keuangan, kegiatan produksi dan operasi (Tabel 2). Berdasarkan hasil identifikasi faktor internal, terdapat beberapa kekuatan yang dapat dimanfaatkan untuk menuju pertanian organik. Poktan sebagai wadah belajar dan tempat untuk memperkuat kerjasama diantara para Petani memiliki peranan penting dalam menghadapi tantangan, ancaman, hambatan dan gangguan, serta meningkatkan kesejahteraan Petani. Hubungan baik antara ketua dan anggota Poktan dapat mencapai skala ekonomi, baik kuantitas, mutu, maupun kontinuitas.

Kekuatan lain yang dimiliki oleh Poktan adalah sayuran yang diproduksi beraneka ragam, sehingga mampu memenuhi kebutuhan masyarakat. Sayuran yang dihasilkan aman dikonsumsi (Prima III) dan pertanian ramah lingkungan juga menjadi modal untuk menuju pertanian organik. Beberapa hal yang menjadi kelemahan menuju pertanian organik di Pangalengan, antara lain kualifikasi SDM (petani, atau anggota Poktan) masih rendah. Selian itu, keinginan para Petani untuk beralih ke pertanian organik sebenarnya sudah ada, namun para Petani engan untuk memproduksi sayuran organik, karena harga sayuran yang diproduksi secara konvensional hampir sama dengan harga sayuran yang diproduksi secara organik.

Keterbatasan akses pasar juga merupakan kelemahan untuk mengembangkan pertanian organik. Hal ini terjadi karena belum ada pasar dan saluran distribusi produk organik di Pangalengan. Kurangnya promosi, biaya produksi sayuran organik yang tinggi (terutama sertifikasi), keterbatasan modal dan mahalnya biaya transportasi merupakan bagian dari kelemahan yang dihadapi para Petani di Pangalengan untuk menuju pengembangan pertanian organik.

\section{Identifikasi faktor eksternal}

Identifikasi terhadap faktor-faktor eksternal menghasilkan rumusan mengenai peluang dan ancaman yang dihadapi. Rumusan peluang dan ancaman tersebut dapat dijadikan pertimbangan bagi pengembangan strategi produksi sayuran organik di Pangalengan. Aspek-aspek yang ditinjau antara lain ekonomi, sosial budaya, demografi, politik, pemerintah, hukum, teknologi dan kompetitif (Tabel 3).

Selama ini sayuran yang diproduksi di Pangalengan masih berada pada tahap Prima III (sayuran aman dikonsumsi) dan profit yang didapatkan masih dapat menutupi biaya produksi. Pertambahan jumlah penduduk yang semakin meningkat, perubahan pola konsumsi dan gaya hidup masyarakat yang cenderung back to nature, loyalitas konsumen organik tinggi, adanya asosiasi pertanian organik, kebijakan pemerintah mengenai progam "Go organik", dukungan pemerintah, kuota permintaan yang belum semua terpenuhi akan mendorong peningkatan permintaan sayuran organik. Bila permintaan sayuran organik tinggi, kemudian diikuti oleh biaya produksi yang 
efisien, serta harga jual tinggi akan memberikan nilai tambah dan peningkatan kesejahteraan para petani. Menurut Rusma et al (2011) strategi harga dapat dilakukan dengan memberikan potongan harga untuk jumlah pembelian tertentu

Berdasarkan identifikasi faktor eksternal, terdapat beberapa ancaman untuk menuju pertanian organik di Pangalengan, diantaranya serangan hama dan penyakit perusak tanaman, iklim dan cuaca yang tidak menentu, tarif ekspor sayuran tinggi, serta konsinyasi harga dari para agen, atau tengkulak.

\section{Analisis Matriks IFE}

Berdasarkan hasil analisis faktor internal, selanjutnya diidentifikasi beberapa hal yang menjadi kekuatan dan kelemahan Poktan. Penetapan bobot dan rating pada kuesioner melibatkan beberapa pihak, antara lain:

1. Ketua Poktan "Katata"

2. Ketua Poktan "Sari Tani"

3. Pedagang atau pengumpul di Pangalengan

4. Pemasok bibit di Pangalengan

5. Asisten Manager "Adi Farm"

6. Farm Manager "Hikmah Farm"

7. Marketing Manager "Hikmah Farm"

8. Ibu Kepala Desa Pangalengan (sebagai perwakilan konsumen)
9. Dinas Pertanian Tanaman Pangan (Bidang Hortikultura) Jawa Barat

Berdasarkan penilaian terhadap faktor kunci internal, total skor rataan IFE 2,260 (Tabel 4). Hal ini dapat diartikan kemampuan Poktan untuk memanfaatkan kekuatan yang ada dan mengatasi kelemahan tergolong rataan. Hasil perhitungan matriks IFE terlihat bahwa sayuran yang diproduksi aman dikonsumsi (skor 0,336) merupakan kekuatan utama dalam strategi produksi sayuran organik di Pangalengan. Dengan demikian, sistem produksi sayuran yang aman dikonsumsi dapat menjadi langkah utama menuju pertanian organik murni. Kelemahan utama dari sistem pertanian organik di Pangalengan adalah keterbatasan modal.

\section{Analisis Matriks EFE}

Matriks EFE berisi peluang dan ancaman yang dihadapi oleh Poktan. Pemberian bobot pada matriks EFE sama seperti pemberian bobot pada matriks IFE. Berdasarkan penilaian terhadap faktor kunci eksternal, total skor rataan EFE 2,790 (Tabel 27). Hal ini dapat diartikan kemampuan Poktan untuk memanfaatkan peluang-peluang yang ada dan mengatasi ancaman-ancaman yang dihadapi oleh Poktan tergolong rataan.

Tabel 2. Faktor internal strategi produksi sayuran organik di Pangalengan

\begin{tabular}{|c|c|c|}
\hline Faktor Internal & Kekuatan & Kelemahan \\
\hline Manajemen & $\begin{array}{l}\text { Hubungan baik yang terjalin antara Ketua } \\
\text { dengan Anggota Poktan }\end{array}$ & Kemampuan SDM masih rendah \\
\hline Pemasaran & & $\begin{array}{l}\text { 1. Harga sayuran organik hampir sama dengan } \\
\text { harga sayuran semi organik. } \\
\text { 2. Lemahnya akses Poktan terhadap pasar } \\
\text { sayuran organik. } \\
\text { 3. Kurangnya promosi sayuran organik }\end{array}$ \\
\hline Keuangan & & $\begin{array}{l}\text { 1. Biaya produksi produk organik terlalu tinggi } \\
\text { 2. Keterbatasan modal }\end{array}$ \\
\hline $\begin{array}{l}\text { Produksi dan } \\
\text { operasi }\end{array}$ & $\begin{array}{l}\text { 1. Sayuran yang diproduksi beraneka } \\
\text { ragam } \\
\text { 2. Kondisi geogafis mendukung } \\
\text { 3. Pertanian ramah lingkungan (Prima } \\
\text { III) } \\
\text { 4. Sayuran yang dihasilkan aman } \\
\text { dikonsumsi }\end{array}$ & $\begin{array}{l}\text { 1. Sertifikasi produk organik belum ada } \\
\text { 2. Mahalnya biaya transportasi }\end{array}$ \\
\hline
\end{tabular}

Tabel 3. Faktor eksternal strategi produksi sayuran organik di Pangalengan

\begin{tabular}{|c|c|c|}
\hline Faktor Eksternal & Peluang & Ancaman \\
\hline Ekonomi & 1. Harga jual lebih tinggi & \\
\hline $\begin{array}{l}\text { Sosial budaya dan } \\
\text { demogafi }\end{array}$ & $\begin{array}{l}\text { 1. Pertambahan jumlah penduduk yang terus } \\
\text { meningkat. } \\
\text { 2. Perubahan pola konsumsi dan gaya hidup } \\
\text { masyarakat yang cenderung back to } \\
\text { nature } \\
\text { 3. Loyalitas konsumen organik tinggi } \\
\text { 4. Asosiasi pertanian organik }\end{array}$ & $\begin{array}{l}\text { 1. Serangan hama dan penyakit } \\
\text { perusak tanaman } \\
\text { 2. Iklim dan cuaca yang tidak } \\
\text { menentu memengaruhi hasil } \\
\text { produksi }\end{array}$ \\
\hline $\begin{array}{l}\text { Politik, pemerintah } \\
\text { dan hukum }\end{array}$ & $\begin{array}{l}\text { 1. Kebijakan pemerintah mengenai progam } \\
\text { "Go organik } 2010 \text { " } \\
\text { 2. Dukungan pemerintah }\end{array}$ & Tarif ekspor sayuran tinggi \\
\hline Kompetitif & Kuota permintaan belum terpenuhi semua & $\begin{array}{l}\text { Konsinyasi harga dari para agen } \\
\text { tengkulak }\end{array}$ \\
\hline
\end{tabular}


Tabel 4. Analisis matriks IFE

\begin{tabular}{|c|c|c|c|c|}
\hline \multicolumn{2}{|c|}{ Faktor - Faktor Internal } & $\begin{array}{c}\text { Bobot } \\
\text { (a) }\end{array}$ & $\begin{array}{l}\text { Rating } \\
\text { (b) }\end{array}$ & $\begin{array}{c}\text { Nilai } \\
\text { Tertimbang } \\
(\mathrm{a} \times \mathrm{b})\end{array}$ \\
\hline \multicolumn{5}{|c|}{ Kekuatan } \\
\hline A & Sayuran yang diproduksi beraneka ragam & 0,073 & 3,5 & 0,255 \\
\hline \multirow{2}{*}{$\begin{array}{l}B \\
C\end{array}$} & Kondisi geografi mendukung & 0,073 & 3,6 & 0,262 \\
\hline & $\begin{array}{l}\text { Hubungan baik yang terjalin antara ketua dengan } \\
\text { anggota kelompok tani }\end{array}$ & 0,064 & 3,3 & 0,210 \\
\hline $\mathrm{D}$ & Pertanian ramah lingkungan (prima III) & 0,079 & 3,8 & 0,302 \\
\hline $\mathrm{E}$ & Sayuran yang dihasilkan aman dikonsumsi & 0,084 & 4,0 & 0,336 \\
\hline \multicolumn{5}{|c|}{ Kelemahan } \\
\hline & $\begin{array}{l}\text { Biaya produksi produk organik terlalu tinggi } \\
\text { Harga sayuran organik hampir sama dengan harga }\end{array}$ & 0,081 & 1,2 & 0,097 \\
\hline & sayuran semi organik & 0,081 & 1,4 & 0,114 \\
\hline \multirow{2}{*}{$\begin{array}{c}\mathrm{H} \\
\mathrm{I}\end{array}$} & Kemampuan SDM masih rendah & 0,081 & 1,5 & 0,121 \\
\hline & $\begin{array}{l}\text { Lemahnya akses kelompok tani terhadap pasar } \\
\text { sayuran organik }\end{array}$ & 0,083 & 1,3 & 0,108 \\
\hline $\mathrm{J}$ & Sertifikasi produk organik belum ada & 0,078 & 1,5 & 0,117 \\
\hline $\mathrm{K}$ & Keterbatasan modal & 0,071 & 1,8 & 0,127 \\
\hline $\mathrm{L}$ & Kurangnya promosi sayuran organik & 0,084 & 1,2 & 0,101 \\
\hline \multirow[t]{2}{*}{$\mathrm{M}$} & Mahalnya biaya transportasi & 0,069 & 1,6 & 0,111 \\
\hline & Total & 1,000 & & 2,260 \\
\hline
\end{tabular}

Tabel 5. Analisis matriks EFE

\begin{tabular}{|c|c|c|c|}
\hline Faktor- Faktor Eksternal & $\begin{array}{l}\text { Bobot } \\
\text { (a) }\end{array}$ & $\begin{array}{l}\text { Rating } \\
\text { (b) }\end{array}$ & $\begin{array}{c}\text { Nilai } \\
\text { Tertimbang } \\
(\mathrm{a} \times \mathrm{b})\end{array}$ \\
\hline \multicolumn{4}{|l|}{ Peluang } \\
\hline $\begin{array}{l}\text { A Pertambahan jumlah penduduk yang terus } \\
\text { meningkat }\end{array}$ & 0,073 & 3,2 & 0,234 \\
\hline $\begin{array}{l}\text { B Perubahan pola konsumsi dan gaya hidup } \\
\text { masyarakat yang cenderung back to nature }\end{array}$ & 0,087 & 3,9 & 0,339 \\
\hline $\begin{array}{l}\text { C Kebijakan pemerintah mengenai program "Go } \\
\text { organik } 2010 "\end{array}$ & 0,086 & 3,6 & 0,310 \\
\hline D Loyalitas konsumen organik tinggi & 0,073 & 3,3 & 0,242 \\
\hline E Asosiasi pertanian organik & 0,069 & 3,0 & 0,208 \\
\hline F Harga jual sayuran organik lebih tinggi & 0,083 & 3,6 & 0,297 \\
\hline G Kuota permintaan belum terpenuhi semua & 0,076 & 3,2 & 0,243 \\
\hline H Dukungan pemerintah & 0,102 & 3,8 & 0,388 \\
\hline \multicolumn{4}{|l|}{ Ancaman } \\
\hline I Serangan hama dan penyakit perusak tanaman & 0,089 & 1,6 & 0,142 \\
\hline $\begin{array}{l}\text { J Iklim dan cuaca yang tidak menentu mempengaruhi } \\
\text { hasil produksi }\end{array}$ & 0,085 & 1,7 & 0,144 \\
\hline $\mathrm{K}$ Konsinyasi harga dari para agen/tengkulak & 0,078 & 1,7 & 0,133 \\
\hline \multirow{2}{*}{$\frac{L \text { Tarif ekspor sayuran tinggi }}{\text { Total }}$} & 0,098 & 1,1 & 0,108 \\
\hline & 1,000 & & 2,790 \\
\hline
\end{tabular}

Pada Tabel 5, terlihat bahwa dukungan pemerintah merupakan peluang yang paling besar dalam menuju pertanian organik (skor 0,388 ). Ancaman utama yang dihadapi dalam produksi sayuran organik adalah iklim dan cuaca yang tidak menentu mempengaruhi hasil produksi (skor 0,144).

\section{Matriks IE}

Dari hasil evaluasi dan analisis yang telah dilakukan, dipertajam dengan analisis internal dan eksternal yang menghasilkan matriks IE untuk mengetahui posisi Poktan saat ini. Pemetaan posisi perusahaan sangat penting bagi pemilihan alternatif strategi dalam menghadapi persaingan dan perubahan yang terjadi. Nilai matriks IFE 2,260 dan EFE 2,790, menunjukkan posisi Poktan di Pangalengan berada pada Kuadran V (hold and maintain), yaitu memiliki kemampuan internal dan eksternal rataan. Poktan yang masuk ke dalam kuadran ini sebaiknya dikelola dengan strategi penetrasi pasar dan pengembangan produk (Gambar 2). 


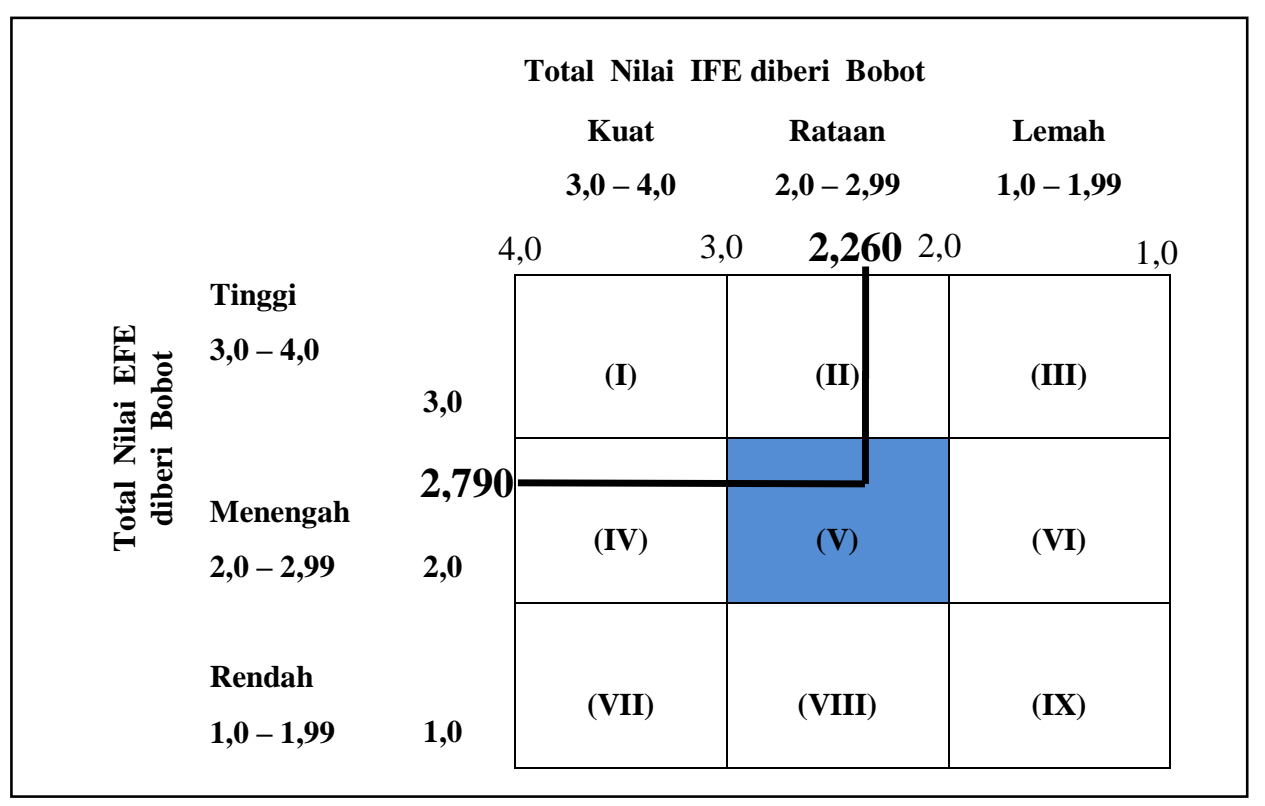

Gambar 2. Analisis matriks IE Poktan di Pangalengan

Tabel 6. Analisis Matriks SWOT

\begin{tabular}{|c|c|c|}
\hline Faktor Eksternal & $\begin{array}{l}\text { Kekuatan (Strengths-S) } \\
\text { 1. Sayuran yang diproduksi } \\
\text { beraneka ragam } \\
\text { 2. Kondisi geogafi } \\
\text { mendukung } \\
\text { 3. Hubungan baik yang } \\
\text { terjalin antara Ketua } \\
\text { dengan Anggota Poktan } \\
\text { 4. Pertanian ramah } \\
\text { lingkungan (Prima III) } \\
\text { 5. Sayuran yang dihasilkan } \\
\text { aman dikonsumsi }\end{array}$ & $\begin{array}{l}\text { Kelemahan (Weakness-W) } \\
\text { 1. Biaya produksi produk organik } \\
\text { terlalu tinggi } \\
\text { 2. Harga sayuran organik hampir } \\
\text { sama dengan harga sayuran } \\
\text { semi organik } \\
\text { 3. Kemampuan SDM masih } \\
\text { rendah } \\
\text { 4. Lemahnya akses kelompok } \\
\text { tani terhadap pasar sayuran } \\
\text { organik } \\
\text { 5. Sertifikasi produk belum ada } \\
\text { 6. Keterbatasan modal } \\
\text { 7. Mahalnya biaya transportasi }\end{array}$ \\
\hline $\begin{array}{l}\text { Peluang (Opportunities-O) } \\
\text { 1. Pertambahan jumlah penduduk } \\
\text { terus meningkat } \\
\text { 2. Perubahan pola konsumsi dan gaya } \\
\text { hidup masyarakat cenderung back } \\
\text { to nature } \\
\text { 3. Kebijakan pemerintah mengenai } \\
\text { program "Go organik } 2010 " \\
\text { 4. Loyalitas konsumen organik tinggi } \\
\text { 5. Asosiasi pertanian organik } \\
\text { 6. Harga jual lebih tinggi } \\
\text { 7. Kuota permintaan belum terpenuhi } \\
\text { 8. Dukungan pemerintah }\end{array}$ & \begin{tabular}{l}
\multicolumn{1}{c}{ Strategi S-O } \\
1. Meningkatkan mutu, \\
kuantitas dan kontinuitas \\
produksi. \\
2. Memperluas pasar dan \\
mempermudah saluran \\
distribusi \\
3. Memfokuskan \\
pengembangan produk \\
sayuran organik \\
premium
\end{tabular} & \begin{tabular}{ll}
\multicolumn{1}{c}{ Strategi W-O } \\
1. & $\begin{array}{l}\text { Fasilitasi dan dukungan } \\
\text { pemerintah }\end{array}$ \\
2. & $\begin{array}{l}\text { Penguatan terhadap aspek } \\
\text { finansial (permodalan) }\end{array}$ \\
3. & $\begin{array}{l}\text { Memenuhi standar mutu } \\
\text { produk sayuran organik }\end{array}$ \\
sesuai keinginan pembeli \\
4. Melakukan kemitraan dengan \\
pasar Swalayan dalam \\
pendistribusian produk \\
sayuran organik
\end{tabular} \\
\hline $\begin{array}{l}\text { Ancaman (Threats-T) } \\
\text { 1. Serangan hama dan penyakit } \\
\text { perusak tanaman } \\
\text { 2. Iklim dan cuaca yang tidak menentu } \\
\text { mempengaruhi hasil produksi } \\
\text { 3. Konsinyasi harga dari para } \\
\text { agen/tengkulak } \\
\text { 4. Tarif eskpor sayuran tinggi }\end{array}$ & \begin{tabular}{l}
\multicolumn{1}{c}{ Strategi S-T } \\
1. Perencanaan pola tanam \\
yang lebih baik \\
2. Pengembangan produk \\
sayuran organik \\
unggulan
\end{tabular} & \begin{tabular}{l}
\multicolumn{1}{c}{ Strategi W-T } \\
1. Melakukan riset pasar \\
sayuran organik dan \\
merencanakan perkembangan \\
pemasarannya \\
2. Memantau dan mengawasi \\
harga sayuran di setiap \\
tingkatan rantai pasok \\
3. Membentuk asosiasi produsen \\
sayuran organik ditingkat \\
Gapoktan dan Poktan
\end{tabular} \\
\hline
\end{tabular}




\section{Analisis Matriks SWOT}

Tujuan dari tahap pencocokan (matriks SWOT) adalah untuk menghasilkan alternatif strategi yang layak. Tidak semua alternatif strategi yang dikembangkan dalam matriks SWOT akan dipilih dan diimplementasikan (Tabel 6). Dengan analisa ini diharapkan kelompok tani dapat menyusun strategi bersaing berdasarkan kombinasi antara faktor-faktor internal dan eksternal yang telah disajikan dalam matriks IFE dan EFE, sehingga pada akhirnya didapatkan strategi yang sesuai berdasarkan posisi dan kondisi Poktan. Dengan pilihan strategi yang tepat, diharapkan dapat memanfaatkan kekuatan dan peluangnya untuk mengurangi kelemahan dan menghadapi ancaman yang ada.

\section{Prioritas Strategi Pengembangan Manajemen Rantai Pasok}

Pemilihan strategi menggunakan AHP, karena AHP memiliki fleksibilitas tinggi, kemampuan mengakomodasi kompleksi-tas permasalahan yang ada ke dalam sebuah hirarki dan kendalanya mengakomodasi konflik diantara para pakar yang memberikan pendapat. Identifikasi untuk tiap masing-masing unsur dalam hirarki AHP dilakukan oleh pendapat tiga orang ahli/pakar dalam pertanian sayuran organic, seperti perwakilan dari praktisi, Kasi Teknologi Subdit Budidaya Tanaman Sayuran, Direktorat Jenderal Hortikultura Kementerian Pertanian sebagai perwakilan dari pemerintah dan staf pengajar Departemen Agronomi dan Hortikultura, Fakultas Pertanian IPB sebagai perwakilan dari akademisi.

\section{Ultimate Goal}

Ultimate Goal dari struktur hirarki ini adalah menyusun konsep strategi persiapan pengembangan rantai pasok sayuran organik di Kecamatan Pangalengan, Kabupaten Bandung. Harapan strategi yang diperoleh adalah strategi mengembangkan dan menciptakan rantai pasok menuju pertanian sayuran organik di Pangalengan.

\section{Faktor}

Faktor-faktor utama yang berpengaruh nyata dalam pengembangan manajamen rantai pasok adalah SDM, modal, potensi pasar, dan dukungan pemerintah.

\section{Aktor}

Aktor-aktor utama yang berpengaruh terhadap strategi pengembangan manajemen rantai pasok sayuran organik di Pangalengan adalah petani dan pedagang, pemerintah, lembaga riset dan perguruan tinggi, lembaga keuangan, dan konsumen.

\section{Tujuan}

Tujuan penyusunan strategi manajemen rantai pasok sayuran organik di Pangalengan adalah:

a. Mengidentifikasi faktor-faktor internal dan eksternal yang memengaruhi manajemen rantai pasok sayuran organik di Pangalengan

b. Mengidentifikasi peranan para pelaku rantai pasok sayuran di Pangalengan

c. Menyusun strategi rantai pasok yang tepat untuk sayuran organik bernilai tambah tinggi berbasis petani di Pengalengan

\section{Alternatif Strategi}

Alternatif strategi pengembangan manajemen rantai pasok yang diperoleh melalui analisis SWOT adalah:

a. Meningkatkan mutu, kuantitas dan kontinuitas produksi

b. Memperluas pasar/kemitraan dan mempermudah saluran distribusi

c. Fasilitasi dan dukungan pemerintah, serta asosiasi antar petani

d. Penguatan aspek finansial (modal)

e. Perencanaan pola tanam yang lebih baik

f. Melakukan riset pasar sayuran organik dan perencanaan pengembangan pemasarannya

g. Memantau dan mengawasi harga

\section{Analisis Pemilihan Strategi Rantai Pasok}

\section{Hubungan faktor dan ultimate goal}

Tabel 7 menunjukkan hubungan antara faktor dan goal dalam struktur hirarki AHP. Faktor yang dianggap paling penting terhadap konsep strategi pengembangan manajemen rantai pasok sayuran organik di Kecamatan Pangalengan adalah modal dengan bobot 0,375. Modal merupakan faktor awal untuk menerapkan dan mengembangkan pertanian sayuran menuju organik di Pangalengan. Tanpa adanya pembiayaan dan modal yang cukup, para petani tidak akan tergerak untuk memproduksi sayuran organik di Pangalengan.

Tabel 7. Hubungan faktor dan goal

\begin{tabular}{ll}
\hline Faktor/UG & $\begin{array}{l}\text { Konsep strategi pengembangan manajemen rantai pasok } \\
\text { sayuran organik di Kecamatan Pangalengan - Bandung }\end{array}$ \\
\hline SDM & 0,166 \\
Dukungan Pemerintah & 0,228 \\
Potensi Pasar & 0,231 \\
Modal & $\mathbf{0 , 3 7 5}$ \\
\hline
\end{tabular}




\section{Hubungan faktor dan aktor}

Aktor yang paling mempengaruhi SDM adalah petani dan pedagang dengan bobot 0,383 (Tabel 8). Para petani merupakan orang pertama yang akan memproduksi sayuran organik dan sekaligus sebagai produsen untuk rantai pasok distribusi sayuran organik. Aktor yang paling mempengaruhi faktor modal adalah konsumen dan lembaga keuangan (bobot 0,299 ). Dalam hal ini lembaga keuangan adalah untuk dukungan dan penguatan finansial.

Aktor yang paling memengaruhi faktor potensi pasar adalah konsumen dengan bobot 0,443 . Hal ini karena konsumen merupakan tujuan utama dari suatu produk diproduksi apabila tidak ada konsumen maka tidak akan tercipta suatu pasar. Aktor yang paling mempengaruhi faktor dukungan pemerintah di Pangalengan adalah lembaga keuangan (bobot 0,364 yang berupa bank pemerintah yang ikut serta dalam mendukung pembiayaan pertanian organik di Pangalengan.

\section{Hubungan aktor dan tujuan}

Bagi petani dan pedagang, pemerintah, lembaga riset dan perguruan tinggi, serta konsumen, tujuan yang paling dianggap penting adalah menyusun strategi rantai pasok yang sesuai untuk sayuran organik bernilai tambah tinggi berbasis petani di Pangalengan dengan bobot berturut-turut $0,460,0,600,0,685$ dan 0,584 (Tabel 9). Dari sisi aktor, lembaga keuangan mengganggap tujuan yang paling penting adalah mengidentifikasi peranan para pelaku rantai pasok sayuran di Pangalengan (bobot 0,600).

\section{Hubungan tujuan dan alternatif strategi}

Alternatif memperluas pasar/kemitraan, mempermudah saluran distribusi, serta melakukan riset pasar sayuran organik dan perencanaan pengembangan pemasarannya dianggap merupakan alternatif-alternatif paling penting untuk mencapai tujuan mengidentifikasi faktor-faktor internal dan eksternal yang memengaruhi manajemen rantai pasok sayuran organik di Pangalengan dengan bobot 0,217 (Tabel 10). Alternatif perencanaan pola tanam yang lebih baik merupakan alternatif paling penting untuk tujuan mengidentifikasi peranan para pelaku rantai pasok sayuran di Pangalengan dengan bobot 0,342. Untuk tujuan menyusun strategi rantai pasok yang sesuai untuk sayuran organik bernilai tambah tinggi berbasis petani di Pangalengan, alternatif strategi yang dianggap paling penting adalah memperluas pasar dan mempermudah saluran distribusi dengan bobot 0,239 .

Tabel 8. Hubungan faktor dan aktor

\begin{tabular}{lcccc}
\hline \multicolumn{1}{c}{ Aktor/faktor } & SDM & Modal & Potensi Pasar & $\begin{array}{c}\text { Dukungan } \\
\text { Pemerintah }\end{array}$ \\
\hline Petani dan Pedagang & $\mathbf{0 , 3 8 3}$ & 0,061 & 0,082 & 0,113 \\
Pemerintah & 0,107 & 0,244 & 0,169 & 0,149 \\
Lembaga Riset dan & 0,087 & 0,104 & 0,169 & 0,160 \\
Perguruan Tinggi & & & & \\
Lembagan Keuangan & 0,163 & $\mathbf{0 , 2 9 9}$ & 0,137 & $\mathbf{0 , 3 6 4}$ \\
Konsumen & 0,260 & 0,292 & $\mathbf{0 , 4 4 3}$ & 0,215 \\
\hline
\end{tabular}

Tabel 9. Hubungan aktor dan tujuan

\begin{tabular}{|c|c|c|c|c|c|}
\hline Tujuan/Aktor & $\begin{array}{l}\text { Petani dan } \\
\text { Pedagang }\end{array}$ & Pemerintah & $\begin{array}{l}\text { Lembaga Riset dan } \\
\text { Perguruan Tinggi }\end{array}$ & $\begin{array}{l}\text { Lembaga } \\
\text { Keuangan }\end{array}$ & Konsumen \\
\hline $\begin{array}{l}\text { Mengidentifikasi faktor-faktor inter- } \\
\text { nal dan eksternal yang mempenga- } \\
\text { ruhi manajemen rantai pasok } \\
\text { sayuran organik di Pangalengan }\end{array}$ & 0,221 & 0,200 & 0,200 & 0,234 & 0,281 \\
\hline $\begin{array}{l}\text { Mengidentifikasi peranan para } \\
\text { pelaku rantai pasok sayuran di } \\
\text { Pangalengan }\end{array}$ & 0,319 & 0,200 & 0,600 & 0,080 & 0,135 \\
\hline $\begin{array}{l}\text { Menyusun strategi rantai pasok } \\
\text { yang sesuai untuk sayuran organik } \\
\text { bernilai tambah tinggi berbasis } \\
\text { petani di Pangalengan }\end{array}$ & 0,460 & 0,600 & 0,200 & 0,685 & 0,584 \\
\hline
\end{tabular}


Tabel 10. Hubungan tujuan dan alternatif strategi

\begin{tabular}{lccc}
\hline Alternatif Strategi/Tujuan & $\begin{array}{l}\text { Mengidentifikasi faktor-faktor } \\
\text { internal dan eksternal yang } \\
\text { mempengaruhi manajemen } \\
\text { rantai pasok sayuran organik } \\
\text { di Pangalengan }\end{array}$ & $\begin{array}{l}\text { Mengidentifikasi } \\
\text { peranan para } \\
\text { pelaku rantai pasok } \\
\text { sayuran di } \\
\text { Pangalengan }\end{array}$ & $\begin{array}{l}\text { Menyusun strategi rantai } \\
\text { pasok yang sesuai untuk } \\
\text { sayuran organik bernilai } \\
\text { tambah tinggi berbasis } \\
\text { petani di Pangalengan }\end{array}$ \\
\hline $\begin{array}{l}\text { Meningkatkan mutu, } \\
\text { kuantitas dan kontinuitas } \\
\text { produksi }\end{array}$ & 0,054 & 0,240 & 0,041 \\
\hline $\begin{array}{l}\text { Memperluas pasar/kemit- } \\
\text { raan dan mempermudah } \\
\text { saluran distribusi }\end{array}$ & $\mathbf{0 , 2 1 7}$ & 0,079 & $\mathbf{0 , 2 3 9}$ \\
\hline $\begin{array}{l}\text { Fasilitasi dan dukungan } \\
\text { pemerintah, serta asosiasi } \\
\text { antar petani }\end{array}$ & 0,202 & 0,083 & 0,163 \\
\hline $\begin{array}{l}\text { Penguatan aspek finansial } \\
\text { (modal) }\end{array}$ & & 0,074 & 0,155 \\
\hline $\begin{array}{l}\text { Perencanaan pola tanam } \\
\text { yang lebih baik }\end{array}$ & 0,054 & 0,342 & 0,060 \\
\hline $\begin{array}{l}\text { Melakukan riset pasar } \\
\text { sayuran organik dan } \\
\text { perencanaan pengem- } \\
\text { bangan pemasaran }\end{array}$ & 0,054 & 0,097 & 0,185 \\
\hline $\begin{array}{l}\text { Memantau dan } \\
\text { mengawasi harga }\end{array}$ & $\mathbf{0 , 2 1 7}$ & & 0,158 \\
\hline
\end{tabular}

\section{Analisis Pemilihan Strategi Rantai Pasok}

\section{Faktor}

Tabel 11 menunjukkan faktor modal merupakan faktor prioritas pertama dalam pencapaian goal dari kajian ini dengan bobot 0,375. Kemudian faktor lain berturut-turut berdasarkan prioritas paling tinggi ke rendah adalah potensi pasar $(0,231)$, dukungan pemerintah $(0,228)$ dan $\operatorname{SDM}(0,166)$.

Tabel 11. Bobot faktor terhadap goal

\begin{tabular}{lcc}
\hline Faktor & Bobot & Prioritas \\
\hline Modal & $\mathbf{0 , 3 7 5}$ & $\mathbf{1}$ \\
Potensi Pasar & 0,231 & 2 \\
Dukungan Pemerintah & 0,228 & 3 \\
SDM & 0,166 & 4 \\
\hline
\end{tabular}

Aktor

Dalam mencapai keberhasilan dari kajian ini aktor yang paling mempengaruhi goal adalah konsumen (0,306). Hal ini menunjukkan konsumen menjadi aktor untuk dapat menggerakkan dan menjadi tujuan utama dalam penyusunan konsep strategi rantai pasok di Pangalengan. Data lengkapnya dapat dilihat pada Tabel 12 .

Tabel 12. Bobot aktor terhadap goal

\begin{tabular}{lcc}
\hline Aktor & Bobot & Prioritas \\
\hline Konsumen & $\mathbf{0 , 3 0 6}$ & $\mathbf{1}$ \\
Lembaga Keuangan & 0,252 & 2 \\
Pemerintah & 0,183 & 3 \\
Petani dan Pedagang & 0,145 & 4 \\
Lembaga Riset dan Perguruan & 0,128 & 5 \\
Tinggi & & \\
\hline
\end{tabular}

\section{Tujuan}

Tabel 13 menunjukkan bobot tujuan terhadap goal, yaitu menyusun konsep strategi pengembangan manajemen rantai pasok sayuran organik di Kecamatan Pangalengan. Tujuan menyusun strategi rantai pasok yang sesuai untuk sayuran organik bernilai tambah tinggi berbasis petani di Pangalengan (bobot $0,375)$ merupakan prioritas utama dalam pencapaian goal. Artinya strategi yang sesuai harus diutamakan agar tercipta goal. Prioritas tujuan kedua mengidentifikasi peranan para pelaku rantai pasok sayuran di Pangalengan dengan bobot 0,180 . Kemudian prioritas terakhir adalah mengidentifikasi faktor-faktor internal dan eksternal yang mempengaruhi manajemen rantai pasok sayuran organik di Pangalengan (bobot 0,153).

Tabel 13. Bobot tujuan terhadap goal

\begin{tabular}{lcc}
\hline Tujuan & Bobot & Prioritas \\
\hline $\begin{array}{l}\text { Menyusun strategi rantai pasok } \\
\text { yang sesuai untuk sayuran }\end{array}$ & $\mathbf{0 , 3 7 5}$ & $\mathbf{1}$ \\
$\begin{array}{l}\text { organik bernilai tambah tinggi } \\
\text { berbasis petani di Pangalengan }\end{array}$ & & \\
\hline $\begin{array}{l}\text { Mengidentifikasi peranan para } \\
\text { pelaku rantai pasok sayuran di }\end{array}$ & 0,180 & 2 \\
Pangalengan & & \\
\hline $\begin{array}{l}\text { Mengidentifikasi faktor-faktor } \\
\text { internal dan eksternal yang } \\
\text { memengaruhi manajemen } \\
\text { rantai pasok sayuran organik di } \\
\text { Pangalengan }\end{array}$ & & \\
\hline
\end{tabular}

\section{Alternatif strategi}

Tabel 14 menunjukkan bobot alternatif strategi terhadap goal, yaitu menyusun konsep strategi pengembangan manajemen rantai pasok sayuran organik di Kecamatan 
Pangalengan. Alternatif strategi dengan prioritas utama adalah memperluas pasar/kemitraan serta mempermudah saluran distribusi dengan $(0,205)$. Hal ini menunjukkan bahwa untuk mencapai goal dalam kajian ini, saluran distribusi dan perluasan pasar merupakan strategi utama yang harus diterapkan, kemudian diurutan kedua melakukan riset pasar sayuran organik dan perencanaan pengembangan pemasaran $(0,180)$. Hal tersebut berkaitan dengan mencari peluang pasar untuk mengembangkan dan memasarkan sayuran organik di Pangalengan.

Alternatif strategi ketiga adalah fasilitasi dan dukungan pemerintah, serta asosiasi antar petani $(0,157)$. Dalam strategi ini peran pemerintah sebagai fasilitator dan pendukung sangat dibutuhkan untuk mencapai goal. Prioritas strategi keempat adalah memantau dan mengawasi harga dengan bobot 0,156 . Alternatif strategi ini dapat diterapkan bersama dengan strategi prioritas ketiga, yaitu dengan dukungan dari pemerintah. Penguatan aspek finansial (modal) merupakan alternatif prioritas kelima $(0,114)$. Untuk alternatif keenam dan ketujuh berturut-turut, yaitu perencanaan pola tanam yang lebih baik $(0,107)$ dan meningkatkan mutu, kuantitas dan kontinuitas produksi $(0,081)$. Kedua alternatif terakhir tersebut berkaitan dengan produksi dari sayuran organik.

Tabel 14. Bobot alternatif strategi terhadap goal

\begin{tabular}{lcc}
\hline Alternatif Strategi & Bobot & Prioritas \\
\hline $\begin{array}{l}\text { Memperluas pasar/kemitraan } \\
\text { serta mempermudah saluran } \\
\text { distribusi }\end{array}$ & $\mathbf{0 , 2 0 5}$ & $\mathbf{1}$ \\
\hline $\begin{array}{l}\text { Melakukan riset pasar sayuran } \\
\text { organik dan perencanaan } \\
\text { pengembangan pemasaran }\end{array}$ & 0,180 & 2 \\
\hline $\begin{array}{l}\text { Fasilitasi dan dukungan } \\
\text { pemerintah serta asosiasi antar } \\
\text { petani }\end{array}$ & 0,157 & 3 \\
\hline $\begin{array}{l}\text { Memantau dan mengawasi } \\
\text { harga }\end{array}$ & 0,156 & 4 \\
\hline $\begin{array}{l}\text { Penguatan aspek finansial } \\
\text { (modal) }\end{array}$ & 0,114 & 5 \\
\hline $\begin{array}{l}\text { Perencanaan pola tanam yang } \\
\text { lebih baik }\end{array}$ & 0,107 & 6 \\
\hline $\begin{array}{l}\text { Meningkatkan mutu, kuantitas } \\
\text { dan kontinuitas produksi }\end{array}$ & 0,081 & 7 \\
\hline
\end{tabular}

\section{Implikasi Manajerial}

Berdasarkan hasil analisis SWOT dan pengambilan keputusan dengan AHP, maka dapat dilihat bahwa alternatif strategi yang paling baik adalah memperluas pasar dan mempermudah saluran distribusi. Pengembangan pasar dilakukan dengan memperluas saluran distribusi dan pemasarannya. Hal ini dapat dilakukan melalui peningkatan promosi, membuka gerai di supermarket atau tempat lain dan melalui iklan, atau internet. Di Kecamatan Pangalengan saluran distribusi sayuran yang sudah ada tidak tersusun dengan manajemen yang baik.
Beberapa Poktan saja yang memiliki kemitraan dengan perusahaan besar, tetapi kelompok atau petani lain hanya melakukan penjualan dan distribusi yang tidak terencana dan tidak konsisten. Hal tersebut juga dikarenakan pasar untuk penjualan kurang luas dan adanya aliran rantai pasokan sayuran yang terlalu panjang telah menyebabkan penjualan tidak tertata dengan baik.

Kegiatan konkrit dari strategi ini memerlukan dukungan dari pemerintah, terutama pemerintah Kabupaten Bandung yang berwenang dalam mengambil kebijakan dan memutuskan beberapa peraturan agribisnis di Pangalengan. Salah satu dukungan yang sangat diperlukan saat ini adalah sertifikasi untuk lahan dan produk organik.

Berdasarkan rantai pasok yang sudah ada, ada beberapa aliran rantai yang panjang, karena bertujuan untuk memperluas jangkauan distribusi dan pasar, terlepas dari pemotongan mata rantai pasok sulitnya petani untuk mendapatkan pendapatan yang lebih baik.

\section{KESIMPULAN}

a. Rantai pasok sayuran di Kecamatan Pangalengan meliputi pemasok bibit, petani, pedagang/pengumpul, perusahaan, penjual/ eksportir, pasar luar negeri, pasar tradisional dan ritel/supermarket. Panjang, ataupun pendeknya suatu rantai pasok sayuran tersebut tergantung dari pengelolaan manajemen pemasaran dari para Poktan di Pangalengan itu sendiri. Misal rantai pasok yang panjang berarti saluran distribusi dan jangkauan pasar sangat luas dan sebaliknya, rantai pasok pendek melalui jangkauan pasar dan distribusi terbatas, namun nilai lebih bisa diperoleh dari petani (produsen).

b. Setiap anggota atau pelaku rantai pasokan sayuran di Pangalengan mempunyai peran berbeda. Pada tingkatan produsen, pelakunya pemasok bibit dan petani (Poktan) yang melakukan budidaya bibit dan sayuran; ditingkat distributor, pelakunya pedagang/ pengumpul, perusahaan dan eksportir; ditingkat konsumen, terdapat pelaku yang memasarkan sayuran di pasar luar negeri, pasar tradisional, ritel/supermarket dan masyarakat umum.

c. Hasil perhitungan matriks IFE terlihat bahwa sayuran yang diproduksi aman dikonsumsi sebagai kekuatan utama dalam strategi produksi sayuran organik di Pangalengan. Kelemahan utamanya keterbatasan modal. Dukungan pemerintah merupakan peluang paling besar di Pangalengan dalam menuju pertanian organik. Ancaman utama yang dihadapi dalam produksi sayuran organik di Pangalengan, antara lain iklim dan cuaca 
tidak menentu yang memengaruhi hasil produksi.

d. Berdasarkan perumusan alternatif strategi diperoleh 7 strategi, tetapi dengan pembatas kontribusi kerja didapatkan alternatif strategi prioritas utama dan kedua yang berkaitan dengan pemasaran, yaitu memperluas pasar/kemitraan serta mempermudah saluran distribusi; dan melakukan riset pasar sayuran organik dan merencanakan pengembangan pemasaran. Alternatif strategi ketiga mengenai pembinaan/pengawasan, yaitu fasilitasi dan dukungan pemerintah, serta asosiasi antar petani. Alternatif keempat merupakan strategi dalam hal keuangan yaitu memantau dan mengawasi harga.

\section{DAFTAR PUSTAKA}

Admin. 2012. Registrasi Lahan Usaha Sayuran di Kabupaten Bandung Barat. Dinas Pertanian Tanaman Pangan Provinsi Jawa Barat.

http://www.diperta.jabarprov.go.id/index. php/subMenu/informasi/berita/detailberit a/735. [12 Juni 2012].

[AOI] Aliansi Organik Indonesia. 2009. Statistik Pertanian Organik Indonesia 2009. Aliansi Organik Indonesia (AOI), Bogor.
[BPS] Badan Pusat Statistik. 2011. Seksi Integrasi Pengolahan dan Diseminasi Statistik Badan Pusat Statistik Kabupaten Bandung. Badan Pusat Statistik Kabupaten Bandung, Bandung.

Apriantono, A. 2005. "Kebijakan Umum Pembangunan Nasional Dalam Pembangunan Industri Pertanian Mendukung Ketahanan Pangan Nasional', Sambutan Mentri Pertanian Dalam Simposium Nasional Hari Pangan Dunia, Sahid Hotel Jakarta.

David, F. R. 2010. Manajemen Strategis. (Terjemahan). Salemba Empat, Jakarta.

Hadiguna, R. A. dan Marimin. 2007. Alokasi Pasokan Berdasarkan Produk Unggulan Untuk Rantai Pasok Sayuran Segar. Jurnal Teknik Industri; 2(9): 34.

Marimin dan Maghfiroh, N. 2010. Aplikasi Teknik Pengambilan Keputusan dalam Manajemen Rantai Pasok. IPB Press, Bogor.

Nuryati, L. 2012. Mentan Canangkan Gerakan Peningkatan Konsumsi Buah dan Sayuran Nusantara. www.kompas.com.[28 Juni 2012]

Rusma, J., M. Hubeis, dan B. Suharjo. Kajian Preferensi Konsumen Rumah Tangga Terhadap Beras Organik di Wilayah Kota Bogor. Manajemen IKM, 6(1): 49-54. 